\title{
AutocontençÃo NO JUdiciáRIO BrasileIRO: UMA ANÁlise dAs RELAÇÕES ESTRATÉGICAS ENTRE OS PoDERES Constituídos do ESTADO
}

\author{
Juliana de Brito Pontes* \\ José Mário Wanderley Gomes Neto** \\ João Paulo Fernandes de Souza Allain Teixeira***
}

\begin{abstract}
1Introdução. $2 \mathrm{O}$ sistema de controle de constitucionalidade brasileiro e a arguição de descumprimento de preceito fundamental. $3 \mathrm{~A}$ autocontenção no Judiciário brasileiro. 4 Metodologia utilizada. 5 Avaliação dos resultados - análise das relações estratégicas entre os Poderes constituídos do Estado: Executivo vs. Judiciário. 6 Conclusões. Referências.
\end{abstract}

\section{RESUMO}

A arguição de descumprimento de preceito fundamental (ADPF) é um instrumento processual-constitucional tipicamente brasileiro, capaz de impedir atos de ameaça ou violação a preceito fundamental, decorrentes do Poder Público. O contexto marcante da judicialização da política na jurisdição constitucional brasileira evidencia o reduzido número de arguições de descumprimento julgadas. Pretende-se traçar o perfil empírico do funcionamento do controle de constitucionalidade por meio das ADPFs, bem como analisar a ocorrência da autocontenção judicial e o comportamento dos magistrados ao proferirem decisões referentes às ADPFs. Para tanto, houve avaliação quantitativa do total das arguições catalogadas e análise qualitativa das arguições julgadas e não julgadas a partir do estudo de casos abrangendo as ADPFs propostas, sendo distribuídas conforme variáveis e analisada a distribuição de frequências por meio da elaboração de gráficos. Buscou-se compreender a seletividade no julgamento das ADPFs realizada pelo Supremo Tribunal Federal (STF),

* Advogada. Doutoranda em Direito pela Universidade Católica de Pernambuco (UNICAP) na qualidade de Bolsista da CAPES. Mestra em Direito pela Universidade Católica de Pernambuco (2013), na qualidade de bolsista da CAPES. E-mail: <julianabgp@gmail.com>.

** Advogado, Cientista Político, Professor e Pesquisador do PRAETOR - Grupo de estudos sobre Poder Judiciário, Política e Sociedade (UFPE). Possui graduação em Direito pela Universidade Católica de Pernambuco (2000), mestrado em Direito pela Universidade Federal de Pernambuco (2003) e doutorado em Ciência Política pela Universidade Federal de Pernambuco (2015). Professor da Universidade Católica de Pernambuco. E-mail: <jmariow@hotmail.com>.

*** Doutor em Direito pela Universidade Federal de Pernambuco (2005). Mestre em Direito pela Universidade Federal de Pernambuco (1999). Mestre em Teorías Críticas Del Derecho pela Universidad Internacional de Andalucía, Espanha (2000). Graduado em Direito pela Universidade Federal de Pernambuco (1995). Professor Adjunto na Universidade Federal de Pernambuco. Professor na Universidade Católica de Pernambuco e Professor nas Faculdades Integradas Barros Melo. E-mail: <jpallain@hotmail.com>. 
especificando os elementos que motivaram o efetivo processo decisório e os fatores que permitem a prática de autocontenção pela Suprema Corte brasileira. Verificou-se o conflito entre os Poderes Executivo e Judiciário: grande parte das arguições propostas tem como maior violador o próprio Poder Judiciário, porém, quando este profere decisões de mérito nas ADPFs, julga em maioria as ações que tiveram como violador o Poder Executivo, impedindo que as ações contra o Judiciário tenham continuidade, e este seja reconhecido como maior violador dos direitos e garantias fundamentais. Espera-se, com a realização desta pesquisa, contribuir para a compreensão das relações estratégicas entre os Poderes constituídos do Estado.

Palavras-chave: Autocontenção judicial. Poderes do Estado. Arguição de descumprimento de preceito fundamental. Seletividade.

\section{INTRODUÇÃO}

As modificações ocorridas nas ordens constitucionais no período pós Segunda Guerra Mundial (1939-1945) tornaram possível a valorização do Judiciário como poder estatal capaz de solucionar muitos dos conflitos presentes no âmbito social, político, jurídico. A jurisdição constitucional, compreendida como função do Estado cuja finalidade é concretizar os mandamentos inseridos na Constituição da República Federativa do Brasil de 1988 (CRFB/88) ${ }^{1}$, possibilitou que as estruturas normativas abstratas normatizassem a realidade fática.

A jurisdição constitucional teve por fim a afirmação da supralegalidade ao estabelecer as normas infraconstitucionais que deveriam estar vinculadas aos parâmetros estabelecidos pela CRFB/88, tornando possível a prática do controle de constitucionalidade das normas. O termo "jurisdição constitucional", em sua versão contemporânea, está fundamentado na necessidade do estabelecimento de uma instância mediadora, neutra e imparcial para a solução dos conflitos em âmbito constitucional. ${ }^{2}$

Simultaneamente ao desenvolvimento da jurisdição constitucional e à valorização das atividades do Judiciário, os demais poderes públicos tiveram sua capacidade de solução de conflitos reduzida em virtude do aumento da complexidade social e necessidade de um quantitativo maior de normas efetivamente capazes de solucionar os conflitos oriundos dessa sociedade pluralista que surgia. Desse modo, o Judiciário passou a ser considerado pela sociedade como o guardião das garantias e direitos fundamentais e principal poder ao qual poderia recorrer para a solução dos conflitos e satisfação das reivindicações dos grupos de interesses.

Como resultado das modificações nos ordenamentos jurídicos, tornou-se possível a realização do controle de constitucionalidade das normas pelo Poder Judiciário; antes tal atividade era restrita aos Poderes Executivo e Legislativo. A prática de controle normativo, 
tendo se desenvolvido inicialmente na Europa e América do Norte, apresentou como sistemas que exerceram maior influência sobre o controle constitucional brasileiro, ou seja, o controle concentrado e o difuso.

Com o surgimento de novos mecanismos de controle constitucional no Brasil - dentre os quais, a arguição de descumprimento de preceito fundamental - e por meio dos resultados dos julgamentos proferidos em sede de controle concentrado, observa-se que o contexto marcante da judicialização das questões políticas na jurisdição constitucional brasileira evidencia o reduzido número de arguições de descumprimento julgadas.

Buscou-se compreender a seletividade no julgamento das ADPFs realizada pelo Supremo Tribunal Federal (STF), especificando os elementos que motivaram o efetivo processo decisório e os fatores que permitem a prática de autocontenção pela Suprema Corte brasileira. Espera-se, com a realização desta pesquisa, contribuir para a compreensão das relações estratégicas entre os Poderes constituídos do Estado.

\section{O SISTEMA DE CONTROLE DE CONSTITUCIONALIDADE BRASILEIROE A ARGUIÇÃO DE DESCUMPRIMENTO DE PRECEITO FUNDAMENTAL}

No Brasil, a maior valorização das funções judiciais por parte do Constituinte Originário deu-se mediante a promulgação do texto constitucional de 1988, destacando-se a importância do controle normativo realizado pelo Poder Judiciário, que antes sofria restrições por parte dos Poderes Executivo e Legislativo. A partir do controle normativo judicial e diante da necessidade de efetivação dos direitos e garantias fundamentais, novos mecanismos de controle de constitucionalidade foram criados no ordenamento pátrio, dentre eles, a arguição de descumprimento de preceito fundamental (ADPF), que constituiu objeto de estudo deste trabalho.

Por haver sofrido recente processo de democratização, a partir do advento da CRFB/88 e com a adoção do sistema híbrido de controle de constitucionalidade, foi possível verificar no ordenamento jurídico brasileiro a ocorrência de práticas existentes no sistema norte-americano, quais sejam, a existência de judicialização das questões políticas, ativismo judicial e autocontenção judicial.

Possuindo não só a função institucional de guarda da Constituição (art. 102, caput, CRFB/88), o STF exerce também as funções de solucionar as controvérsias e de estabilização da interpretação constitucional no regime de controle de constitucionalidade misto. Logo, a mais alta corte do judiciário brasileiro não é um meio para solucionar questões particulares, mas situações que envolvem maior complexidade e repercussão social.

No sistema de controle de constitucionalidade praticado no Brasil, a revisão judicial exercida tanto sob o âmbito difuso, quanto pelo concentrado, torna possível obter pronunciamentos da mais alta Corte (Supremo Tribunal Federal) por intermédio de recursos ou de 
instrumentos processuais específicos. ${ }^{3}$ Com isso, grupos de oposição (organizações sociais, entidades de classe, partidos políticos) podem recorrer ao Judiciário para promover ou impedir reformas sociais apresentadas por grupos de interesses majoritários, (bancadas políticas, grupos de empresários, dentre outros que detenham maior influência para a obtenção de seus interesses).

No Brasil, a judicialização da política é oriunda do modelo constitucional analítico e do sistema de controle de constitucionalidade adotado. $O$ modelo analítico da Constituição caracteriza-se por apresentar maior detalhamento das normas referentes à organização e ao funcionamento do Estado, maior relação de direitos fundamentais ou de direitos humanos e maior número de regras que regulam situações específicas. ${ }^{4}$

Por ser muito abrangente, a Carta Magna de 1988 tem como guardião final o Judiciário, cuja atuação pode ter início a partir do controle difuso ou de ações específicas. Referida atribuição faz que o Poder Judiciário tenha a palavra final para decidir em diversos casos tanto relacionados a direitos fundamentais quanto a políticas públicas. ${ }^{5}$

Apesar da presença do modelo híbrido de controle constitucional, o Brasil não adotou um tribunal ad hoc, mantendo-se a estrutura do controle misto - controle direto abstrato e incidental concreto -, empregando apenas o instituto da ação de inconstitucionalidade por omissão, oriundo do direito português.

Importante observar que a existência do controle constitucional em sua forma difusa, junto ao controle concentrado, constitui um importante instrumento de filtragem constitucional, por isso a relevância do estudo das peculiaridades que caracterizam o sistema híbrido de controle de constitucionalidade brasileiro. "Com efeito, o controle difuso de constitucionalidade [...] retira do órgão de cúpula do Poder Judiciário o monopólio do controle de constitucionalidade." ${ }^{6}$

A partir da nova Carta Magna, passou a ser observada uma tendência que confere ênfase não mais ao modelo difuso, mas ao modelo concentrado, uma vez que a maior parcela das controvérsias constitucionais foi submetida ao STF, por meio do controle abstrato de normas.

Importante elemento decorrente de tal modificação refere-se ao amplo rol de legitimados à propositura das ações do controle concentrado, possibilitando que pleitos tipicamente individuais sejam conduzidos ao STF mediante ação direta de inconstitucionalidade. . "Assim, o processo abstrato de normas cumpre entre nós dupla função: é a um só tempo instrumento de defesa da ordem objetiva e de defesa de posições subjetivas."

Nessa forma de controle, o Tribunal decidirá acerca da lei em tese, não sendo necessária a existência de um conflito concreto. $\mathrm{O}$ controle concentrado apresenta efeito erga omnes, sendo da competência exclusiva de Tribunal o controle das normas in abstracto. ${ }^{9}$

A partir do controle concentrado, novos mecanismos de compatibilização com o texto Constitucional foram criados: a ação direta de inconstitucionalidade (ADIN); a ação direta 
de inconstitucionalidade por omissão (ADO); a ação declaratória de constitucionalidade (ADC) e a arguição de descumprimento de preceito fundamental (ADPF).

Instituto único no mundo, a arguição de descumprimento de preceito fundamental caracteriza-se por ser um dos instrumentos criados para proteger as diretrizes básicas de consolidação do Estado Democrático de Direito da República Federativa do Brasil. Por meio da ADPF, tem-se por objetivo evitar ou reparar lesão a preceito fundamental decorrente de atos praticados pelo Poder Público e também quando relevante o fundamento da controvérsia constitucional referente à lei ou a ato normativo federal, estadual ou municipal, incluídos os anteriores à Constituição.

A importância da arguição de descumprimento deve-se ao fato de esta permitir a antecipação de decisões sobre controvérsias de teor constitucional relevante, impedindo que a solução venha a ser dada após muitos anos, quando muitas das situações questionadas já sofreram consolidação devido ao lapso temporal. Outro aspecto de destaque é o relativo à proteção das diretrizes básicas de consolidação do Estado Democrático de Direito da República Federativa do Brasil, como a tripartição de poderes, o federalismo e os direitos e garantias fundamentais, estabelecidos pela CRFB/88.

Porém, nem sempre as ADPFs são reconhecidas como meio apto para solucionar descumprimentos aos mandamentos constitucionais: por apresentarem reduzida utilização, poucos são os estudos realizados acerca do processo decisório desse instituto, acarretando o esvaziamento de sua importância no controle de constitucionalidade concentrado.

O presente trabalho teve por objetivo a compreensão da ocorrência da autocontenção judicial nas arguições de descumprimento de preceito fundamental, sendo analisadas as possíveis causas de estagnação do processo decisório das ADPFs, com isso, sendo avaliadas as relações estratégicas entre os poderes constituídos do Estado, ou seja, a existência de conflitos entre os Poderes Executivo e Judiciário.

\section{A AUTOCONTENÇÃO NO JUDICIÁRIO BRASILEIRO}

A ocorrência da judicialização no ordenamento jurídico brasileiro foi objeto de estudo realizado por Ernani Carvalho, ${ }^{10} \mathrm{O}$ qual avaliou o desempenho dos requerentes e atores junto ao STF quando da propositura das ADINs (ações diretas de inconstitucionalidade), tendo por objetivo a melhor compreensão da ocorrência de judicialização da política; as consequências da revisão abstrata da legislação foram usadas como referência na análise de judicialização das ações diretas de inconstitucionalidade. ${ }^{11}$

O ativismo judicial também está presente no sistema jurídico nacional, contudo não será objeto desta pesquisa, pois, conforme anteriormente referido, a judicialização compreende o fenômeno oposto à autocontenção, não sendo o ativismo prática oposta à autocontenção judicial.

Cabe destacar que até o presente momento, a literatura brasileira tem se dedicado ao estudo do ativismo e da judicialização, existindo amplo material referente aos fenômenos. 
Ambos os termos são distintos, portanto não se confundem. Entretanto, pouquíssimos são os trabalhos relacionados ao conteúdo da autorrestrição judicial. $\mathrm{O}$ vocábulo acaba por ter seu conteúdo desgastado, sendo atitude prudente descartar as determinações estabelecidas pelo uso indiscriminado, para tentar-se definir aspectos que caracterizam o fenômeno sob análise, substituindo o efeito paralisante dos clichês. ${ }^{12}$

Embora não muito pesquisada no âmbito jurídico brasileiro, a autocontenção do Judiciário constitui, assim como o ativismo e a judicialização, termo utilizado para referência a fins de abusos judiciais, ou seja, quando houver interesses por parte dos magistrados na resolução ou não de uma questão, alterando, por meio de algumas práticas, o resultado do processo decisório: no ativismo, são aplicadas às decisões hipóteses não previstas diretamente no texto constitucional, ampliando, assim, o conteúdo da interpretação normativa; na judicialização, ocorre a expansão do poder decisório do Judiciário e sua inserção na proteção do sistema político mediante as questões a ele conduzidas por grupos de interesses que objetivam promover alterações nos planos de execução das políticas públicas; na autocontenção, o magistrado utiliza suas preferências políticas e princípios morais para fundamentar a negativa de julgamento de um caso, interferindo, com isso, no resultado da decisão.

A compreensão brasileira acerca da autocontenção judicial difere da norte-americana, a partir desta teve início a prática de restrição de julgamentos proferidos pelos magistrados em determinadas espécies de ações. A literatura jurídica nacional apresenta a autolimitação do Judiciário como sendo a adoção de uma postura respeitosa dos juízes para com os demais poderes estatais, ao evitar interferir nas ações do Executivo e do Legislativo, impedindo, com isso, a aplicação direta da Constituição aos casos não expressamente previstos no seu plano de incidência. Por meio dessa interpretação estrita, o Judiciário passa a depender do pronunciamento do legislador originário para que ocorra o julgamento dessas questões, bem como a abstenção da interferência por juízes e tribunais nas questões de políticas públicas, utilizando critérios conservadores para que haja a declaração de inconstitucionalidade de leis e atos normativos.

De outra maneira, na literatura norte-americana, a judicial self-restraint é verificada quando o juiz utiliza suas preferências políticas e princípios morais para fundamentar a negativa de julgamento de um caso; também, quando age com prudência e cautela na utilização de suas opiniões - e nesse caso, tem-se o denominado "juiz respeitoso", agindo de modo ainda mais limitado do que na primeira situação; há ainda autocontenção quando atua de modo a limitar as práticas políticas sobre o exercício do poder judicial. Portanto, a autocontenção não significa timidez quanto à proclamação das decisões, mas o uso, por parte dos magistrados, de suas preferências políticas e morais para a alteração do resultado de um caso prático, baseando-se na negativa de julgamento e, consequentemente, reduzindo a quantidade de ações que são decididas pelo Tribunal.

Nesse contexto, diferencia-se um juiz autodisciplinado de um juiz autocontido/respeitoso: o primeiro busca decidir um caso sem levar em consideração suas preferências políticas, 
ao passo que o segundo fundamenta a decisão de acordo com seus valores morais e opiniões políticas. No entanto, quanto mais elevado for o tribunal do qual esse juiz faz parte, menor a autodisciplina do julgador, ao acreditar que suas preferências políticas desempenharão um papel favorável na tomada de decisão judicial, podendo, a partir desse aspecto, adotar entre uma das políticas concorrentes - autocontenção ou judicialização.

Verificadas as distinções quanto ao comportamento dos magistrados, observa-se que a autocontenção judicial apresentada pela literatura brasileira assemelha-se ao comportamento do juiz autodisciplinado, não ao juiz autocontido. Assim, a pesquisa foi baseada na autocontenção norte-americana, na qual há a identificação dos fatores e comportamentos de restrição aos julgamentos por parte do Poder Judiciário.

A personalidade do juiz constitui fonte para o surgimento da judicial self-restraint. Um juiz retraído não estaria disposto a enfrentar os demais ramos do governo, sendo, por isso, autocontido, bem como poderia recusar-se a reexaminar as decisões ativistas de seu antecessor. Igualar a judicial self-restraint à inércia do Judiciário constitui uma ideia equivocada - assim como comparar judicialização com ousadia estaria igualmente incorreto.

De modo semelhante à judicialização e ao ativismo, em que as preferências pessoais do juiz se fazem presentes, na autocontenção, este também utiliza tais elementos no processo decisório; assim, diferentemente da ideia errônea que se pode ter acerca da autocontenção - de que o juiz não decide, uma vez que é imparcial - nesta, também é possível que o magistrado utilize suas preferências políticas e morais para justificar a solução de uma questão que lhe foi apresentada. O juiz que não os utiliza é autodisciplinado, não sendo agente no fenômeno da autolimitação do Poder Judiciário.

A autolimitação judicial possui como critério básico o requisito da inconstitucionalidade evidente, claramente identificável, aplicando-se a regra do "caso duvidoso"13, ou seja, na dúvida, prevalece a opção do legislador, devendo o magistrado abster-se de declarar a inconstitucionalidade: in dubio pro legislatore, mas ocorrendo também a situação de muitos dos casos a serem julgados permanecerem aguardando o julgamento, serem declarados prejudicados, não conhecidos ou terem seu seguimento negado - isso pode ser um dos elementos indicativos da ocorrência de autocontenção judicial no ordenamento brasileiro, influenciando o quantitativo de decisões proferidas.

Não havendo a análise de mérito na $\mathrm{ADPF}$, não serão produzidos os efeitos concretos da decisão, o que reduz o número de arguições passíveis de modificarem o âmbito social, político e jurídico. Por isso, o não julgamento do mérito das ADPFs pode caracterizar o comportamento autocontido dos magistrados brasileiros, que se afastam do julgamento das questões concernentes à lesão ao preceito fundamental devido ao fato de, com essa conduta, serem capazes de alterar o resultado do processo decisório das arguições.

O indicativo de comportamento oposto à autocontenção judicial são as respostas do Judiciário diante da judicialização praticada pelos grupos de interesses; nesse caso, estará 
presente uma elevada taxa de julgamentos das questões levadas ao Supremo Tribunal Federal, que, dessa forma, demonstra a vontade dos magistrados em participarem da formulação de políticas públicas (policymaking). Desse modo, será verificado como ocorre o julgamento efetivo (julgamento do mérito) das ações em sede de ADPF, tornando-se o Judiciário mais interventivo e presente na vida política de uma sociedade.

Com isso, a revisão judicial é bastante útil para os grupos políticos de interesses majoritários; não só esses se beneficiam da revisão judicial, como também os grupos de interesses minoritários e os membros do legislativo, vez que o poder de interpretar estatutos e cumprir a lei é, com isso, transferido ao Judiciário. A revisão judicial pode ser utilizada para anular normas aprovadas pelos governantes anteriores ou coligações, desestabilizando a base legislativa que está atualmente em atividade. ${ }^{14}$

No que se refere ao Poder Executivo brasileiro, afirma-se que pouco é verificada a superposição entre este e o Judiciário, no entanto faz-se necessário analisar em capítulo específico a relação existente entre o Poder Executivo e Judiciário, posto que aquele poder também constitui um dos legitimados ativos para a propositura das arguições, elemento este que poderá ser determinante para a ocorrência da autocontenção judicial nas ADPFs.

A partir desse aspecto, foi verificada a ocorrência de autocontenção judicial nas ADPFs, analisando quais elementos contribuem para a prática desse fenômeno pelo Supremo Tribunal Federal. Por meio da análise quantitativa (arguições julgadas e não julgadas) e especificação de variáveis (análise qualitativa), foi possível identificar alguns dos fatores de limitação no processo decisório das ADPFs. Foram objeto de análise todas as arguições de descumprimento de preceito fundamental propostas no STF compreendidas no período de dezembro de 1999 a julho de 2013.

\section{METODOLOGIA UTILIZADA}

A verificação de padrões relativos ao julgamento das ADPFs envolveu aspectos relacionados ao tipo do ato violador do preceito fundamental/origem do ato público questionado (Federal, Estadual ou Municipal), poderes requeridos (legitimados passivos), unidade federativa de origem da ação, requerente (legitimado ativo), assuntos envolvidos, existência de pedido de liminar, resultado da liminar, requisito da subsidiariedade e resultado da arguição.

Para tanto, por meio da análise quantitativa e qualitativa, buscou-se compreender a seletividade negativa e positiva no julgamento das arguições de descumprimento realizada pelo STF, a partir da análise das ações que não sofreram julgamento do mérito e daquelas que tiveram o mérito analisado. Também foi analisado o comportamento dos Ministros do STF com relação ao requisito da subsidiariedade e ao respeito à Lei $9.882 / 99,{ }^{15}$ que regulamenta as arguições de descumprimento. Caracteriza-se também por ser uma pesquisa de caráter exploratório e descritivo por meio do acompanhamento processual da totalidade das ADPFs, por meio do sítio eletrônico do STF - <www.stf.jus.br >. 
Como hipóteses da pesquisa, foi investigado a) se o quantitativo de ADPFs julgadas em relação ao número total de arguições propostas no período de 1993 a 2013 é reduzido, então, constata-se a prática de autocontenção judicial nas ADPFs pelo Supremo Tribunal Federal; b) poucas ADPFs passam pela seletividade positiva e têm seu mérito analisado; c) mesmo presente o requisito da subsidiariedade nas arguições, os Ministros não proferem julgamento, deixando de observar a Lei 9.882/9916 e, por fim, d) as mudanças no quadro de julgamentos das ADPFs ocorrem devido ao comportamento autocontido e seletivo dos Ministros Relatores quando decidem essas ações, também em decorrência dos assuntos e dos requerentes que figuraram nas arguições de descumprimento.

\section{AVALIAÇÃO DOS RESULTADOS - ANÁLISE DAS RELAÇÕES ESTRATÉGICAS ENTRE OS PODERES CONSTITUÍDOS DO ESTADO: EXECUTIVO VS. JUDICIÁRIO}

O primeiro dado analisado compreendeu o total de ADPFs propostas e os aspectos relacionados à seletividade negativa das arguições - aquelas que não sofreram análise no seu mérito. Até o mês de julho de 2013, foi proposto um total de 275 (duzentas e setenta e cinco) ADPFs. Desse quantitativo, apenas 8\% de arguições tiveram seu mérito analisado, enquanto 92\% não sofreram análise em seu conteúdo; desse modo, o conjunto das arguições propostas revela um reduzido percentual de julgamento efetivo pelo STF, conforme pode ser observado no gráfico $\mathrm{n}^{\mathrm{o}} 1$ :

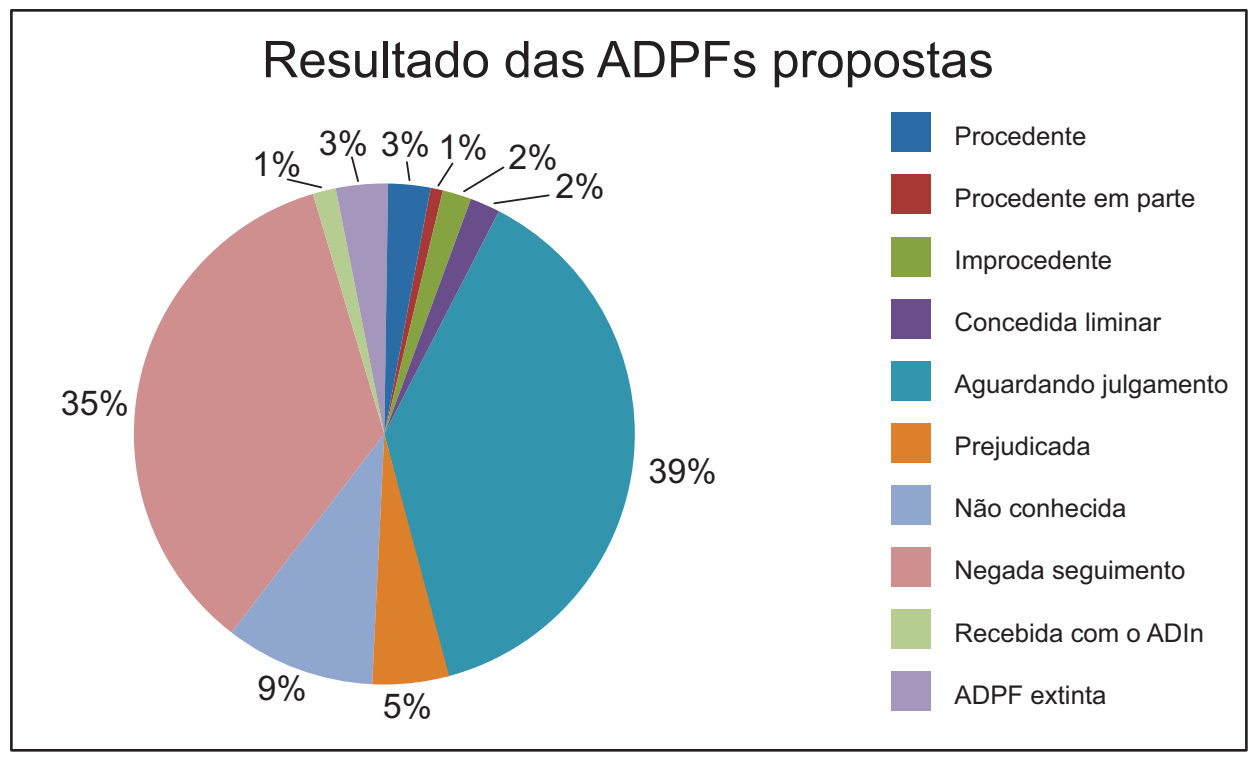

Gráfico 1 - Resultado das ADPFs propostas

Fonte: elaboração própria, a partir de dados colhidos no sítio eletrônico do STF.

Foi identificado que a maioria das arguições propostas teve seu seguimento negado - sofreu seletividade negativa - em decorrência de vícios processuais, grande parte deles compreendendo a ausência dos pressupostos necessários à ação: ilegitimidade ativa ad cau- 
sam e objeto não compreendido como ato do poder público. Esses são alguns dos fatores que podem ser utilizados pelo STF para fundamentar o não conhecimento das arguições, impedindo assim a ocorrência do efetivo processo decisório.

Também foi possível verificar que, em meio ao elevado quantitativo de ADPFs não julgadas, havia um pequeno índice daquelas que não foram solucionadas, mas foram convertidas em ações diretas de inconstitucionalidade. A essas arguições, mesmo apresentando erros formais, deveria ter sido atribuído o status de negado seguimento, no entanto, verificou-se que sofreram análise no mérito em razão de o STF desconsiderar os defeitos de forma nas ADPFs para julgá-las, demonstrando tanto a presença de preferências políticas e morais dos Ministros ao ponto de alterar o resultado final dessas ações, conforme ocorre na judicial self-restraint norte-americana, como destaca que a instrumentalidade das formas é um discurso utilizado pela nossa Suprema Corte para a prática da autocontenção judicial implícita.

No âmbito dos legitimados à propositura das $\mathrm{ADPFs}$, em tese, os maiores requerentes são as confederações sindicais e as entidades de classe de âmbito nacional (78\%), seguidos pelos partidos políticos com representação no Congresso Nacional (67\%), dados esses que destacam a elevada taxa de propositura das ações pelos referidos entes como mecanismo final para a obtenção do cumprimento dos preceitos fundamentais. $O$ dado analisado destacou o uso das arguições, ainda que em número reduzido, como recurso impeditivo às alterações nas políticas públicas realizadas pelos grupos de interesses minoritários, mas que exerceram maior influência política e assim obtiveram êxito na satisfação das suas reivindicações.

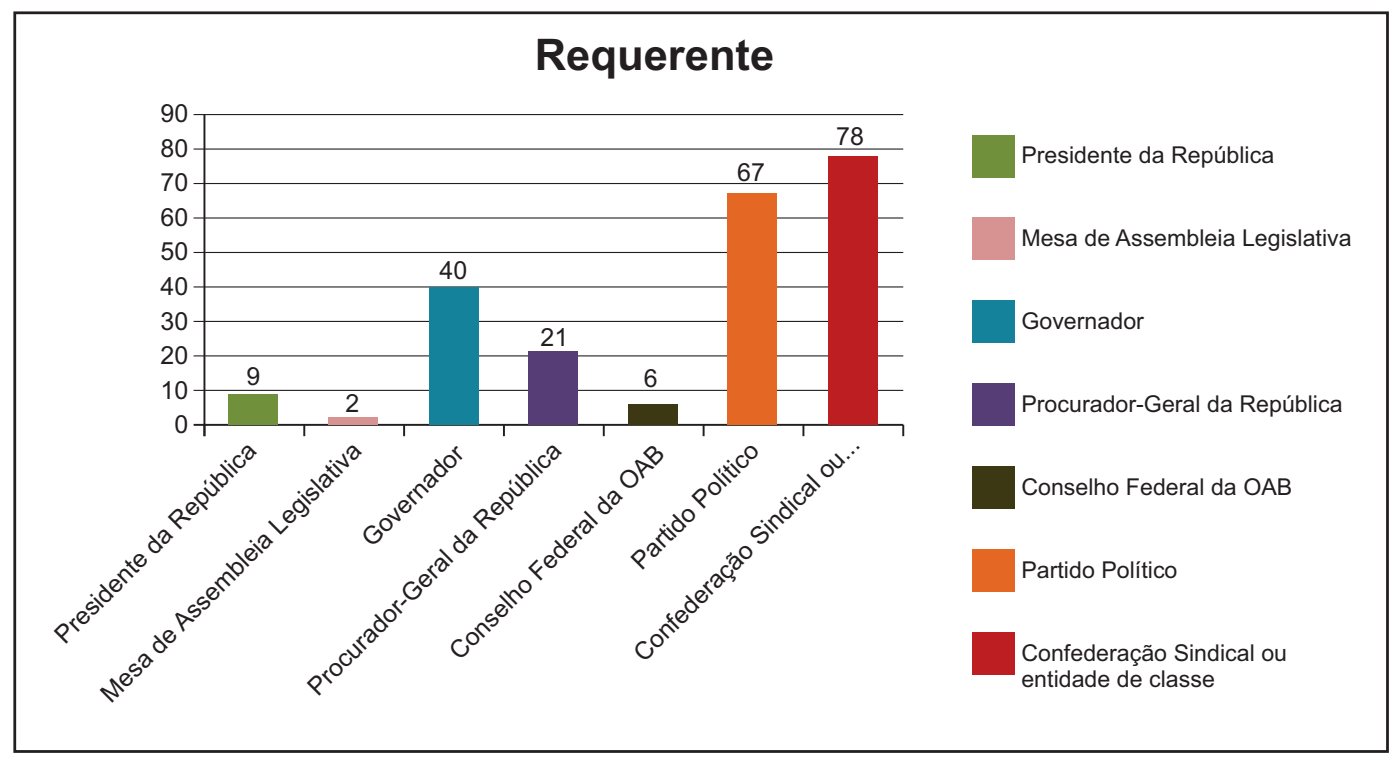

Gráfico 2 - Requerentes nas ADPFs

Fonte: elaboração própria, a partir de dados colhidos no sítio eletrônico do STF.

A propositura das arguições de descumprimento por parte do Poder Executivo no âmbito estadual (40\%), embora em quantitativo menor que os requerentes acima apresen- 
tados, demonstra a necessidade do respeito à soberania do Estado e do princípio federativo, constituindo mais um elemento que conduz ao julgamento das arguições.

Com relação ao pedido de liminar nas ADPFs, foi observado que 94\% das ADPFs traziam o pedido para a sua concessão e apenas 6\% não apresentavam esse elemento. Desses 94\% de arguições com pedido de liminar, $7 \%$ obtiveram sua concessão, das quais $6 \%$ procedentes e $1 \%$ procedente em parte. Os demais pedidos de liminares correspondem a 50\% como sendo as prejudicadas, 38\% aguardam julgamento, e 5\% tiveram provimento negado.

Com base nessas informações, verifica-se que a maior parte das arguições de descumprimento, assim como não tiveram seu mérito julgado, sequer sofreram a análise do pedido de liminar, pois a sua concessão importa na antecipação dos resultados da futura sentença. Desse modo, a presença de autocontenção nas arguições também é reforçada pelo fato de não haver sido dado provimento à maioria dos pedidos de liminar.

Das poucas liminares concedidas, destacaram-se os pedidos de liminar realizados nas arguições propostas pelos Governadores de Estado: foram concedidas em maior parte quando comparadas com os pedidos de liminar feitos pelas entidades de classe de âmbito nacional e com as confederações sindicais. Esse aspecto permitiu a verificação de que o Executivo Estadual foi o maior beneficiado pelo julgamento efetivo de suas ADPFs, assim como aquelas que apresentaram o pedido de liminar.

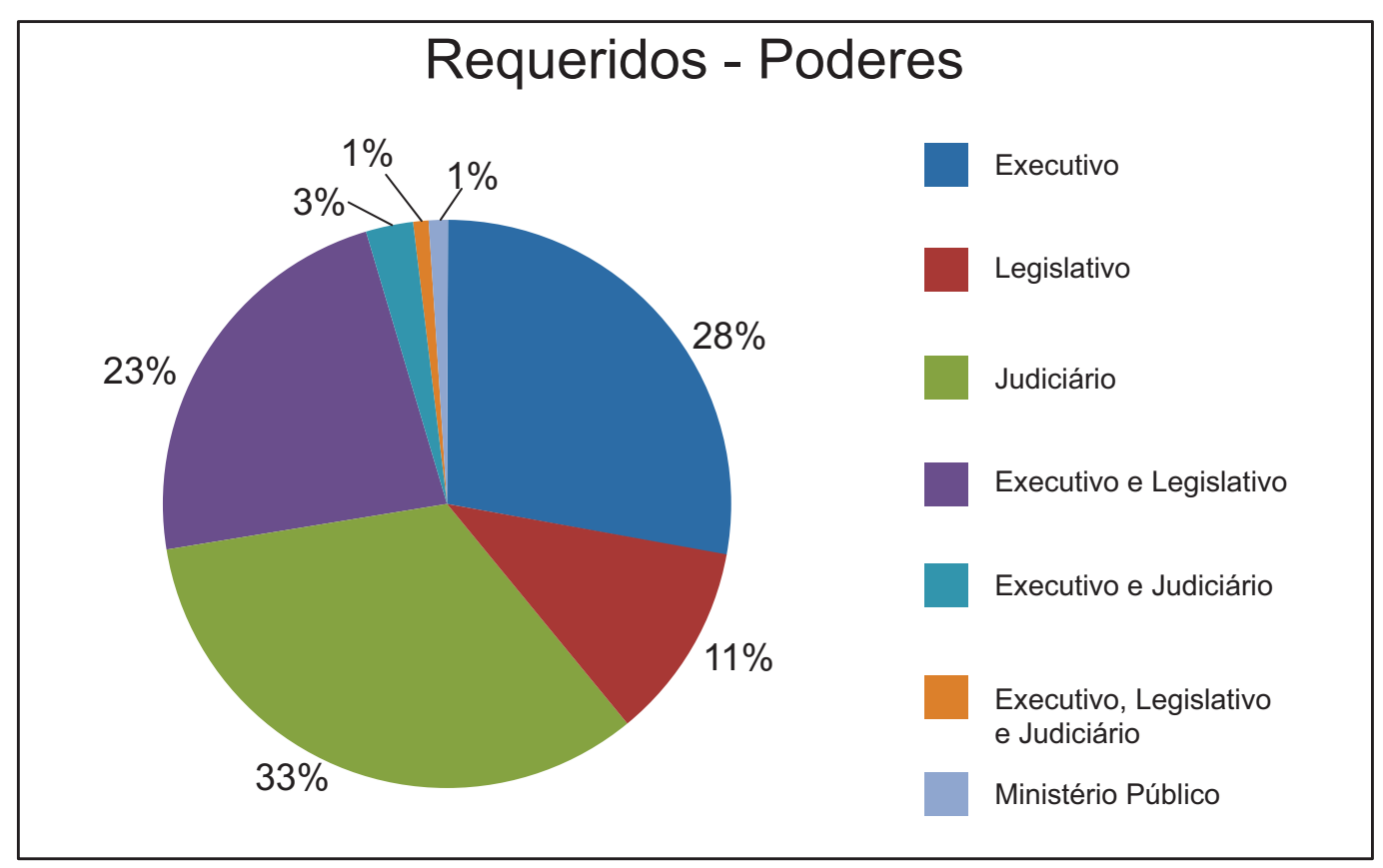

Gráfico 3 - Legitimados passivos (Requeridos - Poderes)

Fonte: elaboração própria, a partir de dados colhidos no sítio eletrônico do STF.

Já em relação aos entes responsáveis pelas violações/ameaças aos preceitos fundamentais, verificou-se que o Poder Judiciário, de modo isolado, foi responsável pelo maior número 
de violações (33\%), tendo este realizado a aplicação de normas infraconstitucionais que vão de encontro às regras da Lei Maior. Para não ser reconhecido como o maior violador dos preceitos que deveria justamente proteger, o Judiciário permanece inerte com relação ao julgamento desses processos, passando a selecionar apenas casos de grande repercussão social e que envolvem atos decorrentes, em sua maioria, do Poder Executivo. Esta é a principal razão pela qual os Ministros não proferem julgamento no âmbito das ADPFs.

Com relação às ADPFs julgadas no mérito, até o período de julho de 2013, apenas $8 \%$ (vinte) ADPFs do total sofreram processo decisório efetivo. Desse modo, o conjunto das arguições propostas revela um reduzido percentual de julgamento pelo STF. Conforme verificado no capítulo antecedente, grande parte das arguições propostas não foi conhecida devido à presença de vícios processuais. $\mathrm{O}$ gráfico $\mathrm{n}^{\mathrm{O}} 4$ apresenta o resultado do julgamento nas ADPFs efetivamente julgadas:

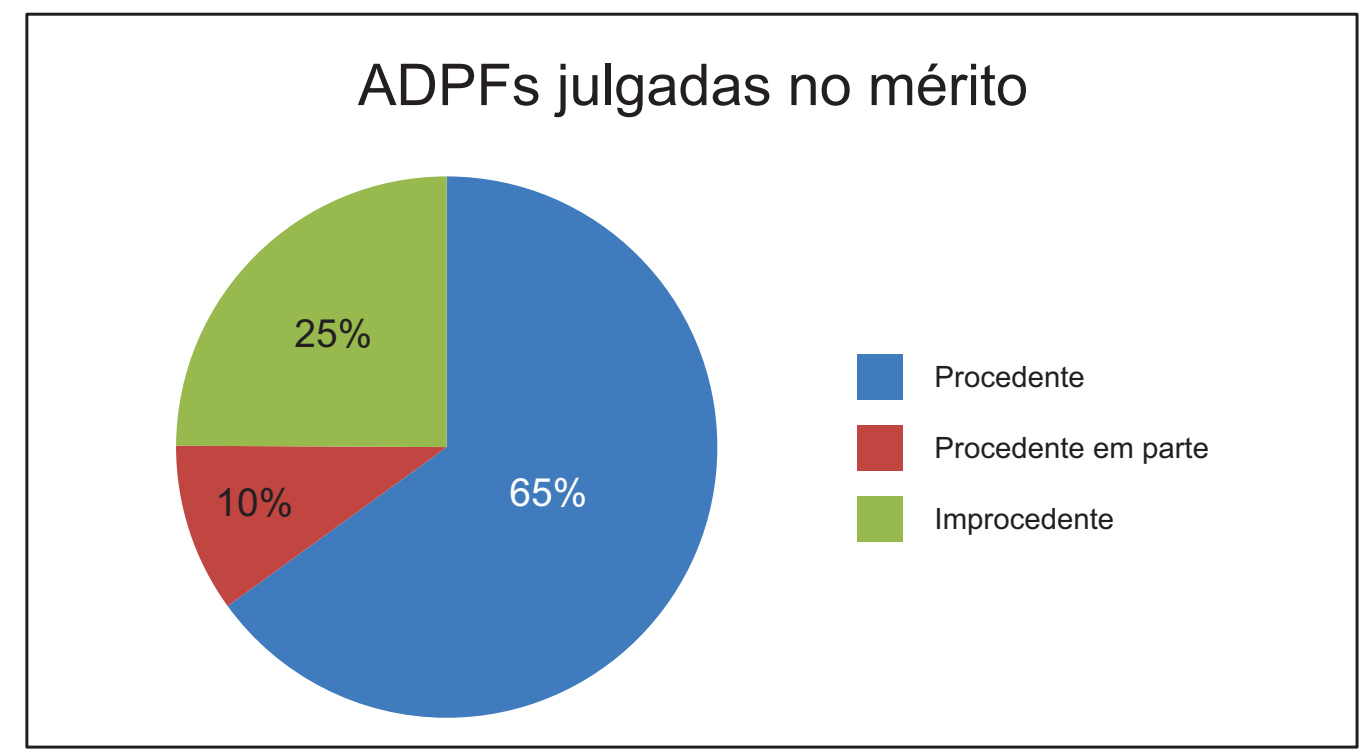

Gráfico 4 - Resultado das ADPFs julgadas no mérito

Fonte: elaboração própria, a partir de dados colhidos no sítio eletrônico do STF.

O julgamento procedente proporciona benefícios ao requerente da ADPF, enquanto a improcedência ou o não julgamento beneficia o ente responsável pela prática da violação ou da ameaça aos preceitos fundamentais. Por meio das arguições julgadas e não julgadas, foi possível observar a ocorrência do conflito entre os Poderes Executivo e Judiciário nas questões levadas ao Supremo, vez que a maior parte das arguições propostas diz tanto respeito ao Poder Executivo, indicado como aplicador de normas inconstitucionais e violador dos preceitos fundamentais por meio de entes da administração pública, quanto às garantias e aos direitos fundamentais relacionados nos artigos $5^{\circ}$ ao $7^{\circ}$ da CRFB/88, sendo o mérito amparado pelo princípio da dignidade humana (gráfico $\mathrm{n}^{\circ} 5$ ). 


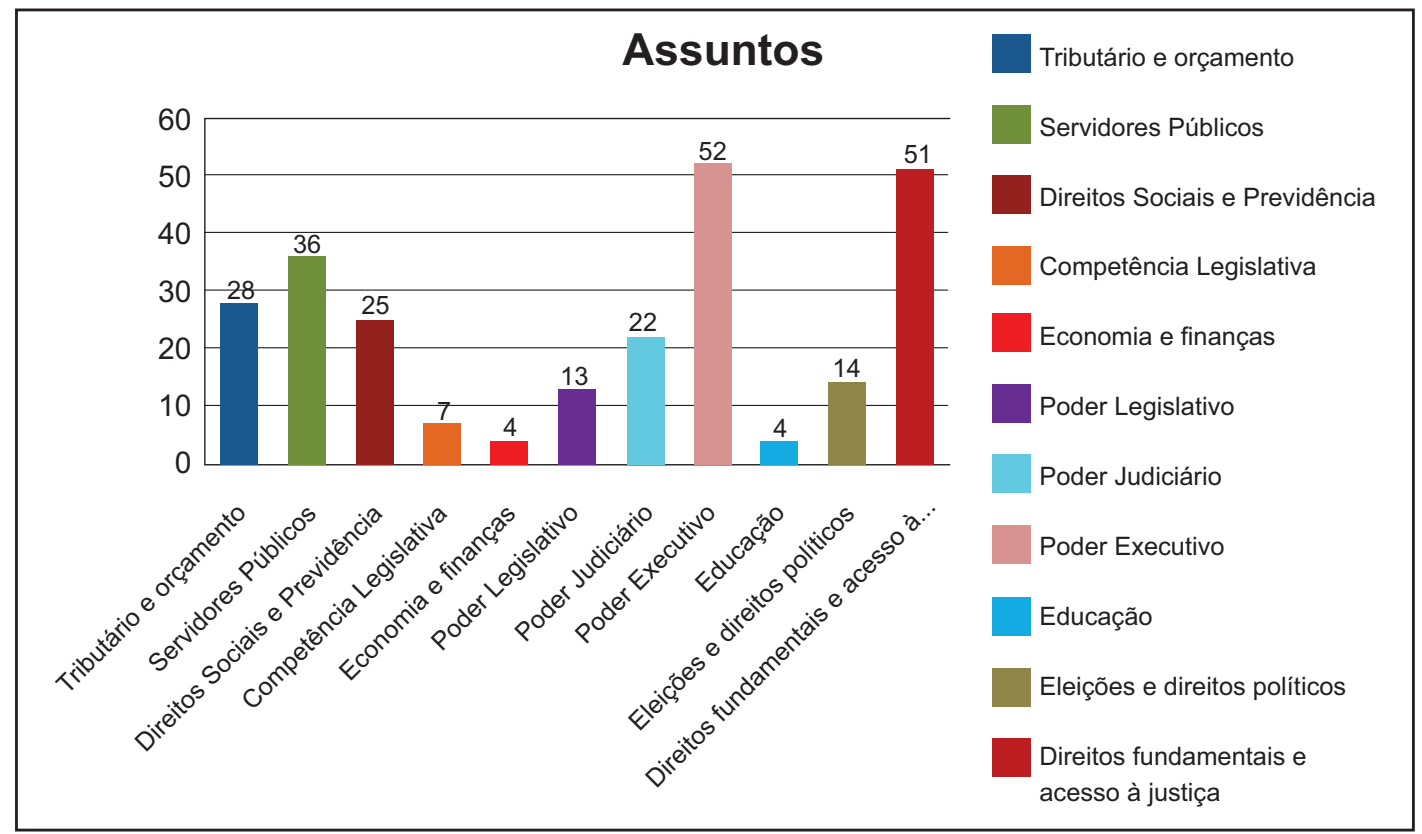

Gráfico 5 - ADPFs por assuntos

Fonte: elaboração própria, a partir de dados colhidos no sítio eletrônico do STF.

O gráfico no 6 apresenta os entes públicos que violaram ou ameaçaram violar os preceitos fundamentais no âmbito das ADPFs efetivamente julgadas. Verifica-se que o Poder Executivo, de modo isolado, foi responsável pelo maior número de violações (45\%), seguido pelo Judiciário (35\%). No total de ADPFs propostas, a situação apresenta uma inversão, sendo o Judiciário o poder que mais ameaça ou viola preceitos fundamentais (33\%), seguido do Poder Executivo, com 28\% das arguições de descumprimento.

\section{Requeridos - Poderes}

Total de ADPF's

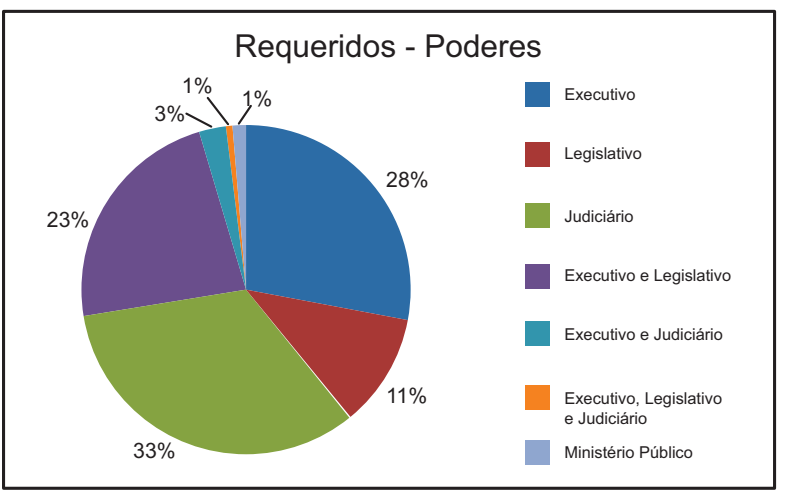

ADPF's julgadas no mérito

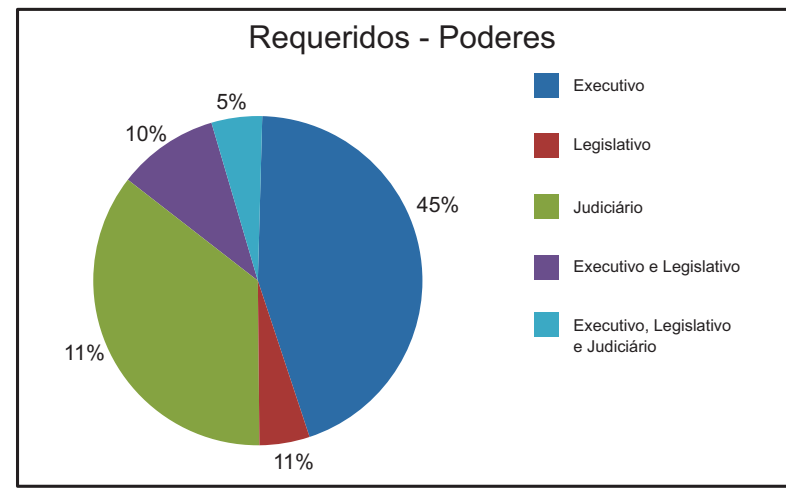

Gráfico 6 - Comparativo - Poderes requeridos no total de ADPFs propostas e nas efetivamente julgadas Fonte: elaboração própria, a partir de dados colhidos no sítio eletrônico do STF.

A comparação realizada entre os legitimados passivos aponta um fator relevante para a explicação do que tem motivado a autocontenção do Judiciário, com a seletividade positiva realizada pelos Ministros nas ADPFs: no âmbito geral, o Judiciário é o maior 
responsável pelas ameaças/violações (33\%); nas que sofreram julgamento efetivo, o Poder Executivo é o maior agente violador dos preceitos fundamentais, correspondendo a $45 \%$ das arguições.

O Poder Legislativo, ao contrário do que se poderia observar, é um dos poderes que menos ameaça/viola os preceitos fundamentais; sua inércia na elaboração de normas e medidas em prol do Estado é um indicativo desse reduzido número de processos (5\%).

Por meio dos percentuais do gráfico $\mathrm{n}^{0} 6$, observa-se que, ao ser proposta uma ADPF em face do Executivo, este exerce controle sobre o Poder Judiciário no momento da prática do ato, mas tal controle não se sobrepõe à autonomia daquele poder, pois a ideia de vigilância e controle recíprocos entre os poderes traz elementos que caracterizam o moderno princípio da separação dos poderes. O que se verifica é que o Judiciário não decide as arguições nas quais ele próprio figurou como violador aos preceitos fundamentais, passando a analisar o mérito das ADPFs propostas contra o Poder Executivo.

Com isso, a afirmativa de que pouco é verificada a superposição entre os Poderes Executivo e Judiciário está equivocada: o Judiciário prioriza o julgamento das arguições oriundas de atos do poder público cuja origem é o Executivo e, desse modo, beneficia-se, mantendo-se como poder que defende preceitos fundamentais constantemente violados pelo Executivo. O não julgar, decorrente da seletividade, representa uma opção política, pois mantém os efeitos do ato impugnado, beneficiando o ente político que editou o ato. $\mathrm{O}$ mesmo efeito que ocorre quando do julgamento improcedente.

Já a seletividade positiva compreende a escolha das ADPFs que serão levadas a julgamento pelo Supremo Tribunal Federal, que, a partir do processo decisório, torna possível a produção de efeitos concretos no âmbito social, político e jurídico. Desse modo, o Supremo Tribunal Federal exerce seletividade tanto em relação às ações diretas de inconstitucionalidade como também nas as arguições de descumprimento a preceito fundamental. Contudo, nestas, a seletividade ocorre de modo ainda mais intenso do que nas ADINs, uma vez que a seletividade das questões políticas se faz presente no controle concentrado de constitucionalidade, quando um reduzido percentual de ações sofre julgamento no mérito.

A análise das ADPFs quanto ao julgamento efetivo, com base nas mesmas variáveis estabelecidas para o total de arguições propostas - quais sejam, tipo do ato violador do preceito fundamental, poderes requeridos, unidade federativa de origem da ação, requerentes, assunto envolvido, existência de pedido de liminar, resultado da liminar, requisito da subsidiariedade, resultado da arguição e ano de julgamento da ADPF - permite confirmar a existência da seletividade positiva no contexto da autocontenção judicial.

As arguições de descumprimento julgadas no mérito apresentaram em comum a busca das confederações sindicais e entidades de classe de âmbito nacional pelo cumprimento do poder público aos preceitos fundamentais resguardados nos arts. $5^{\circ}$ e $7^{\circ}$ da CRFB/88. 
Em seguida, como maior requerente, aparecem os partidos políticos com representação no Congresso Nacional. Esse padrão é repetido quando a análise é realizada no âmbito total da amostra das ADPFs (275 arguições) utilizadas neste trabalho, em que as confederações sindicais e as entidades de classe de âmbito nacional também constituem os maiores requerentes das ações. Desse modo, a inefetividade das instituições majoritárias e sua consequente incapacidade de prover as necessidades revelam a constante procura pela utilização das arguições por minorias como forma de efetivação das demandas sociais.

A subsidiariedade nas ADPFs é considerada "uma condição especial e específica da ação" ${ }^{17}$ que, inexistente, impedirá o conhecimento desse mecanismo de controle constitucional. "Em outros termos, o princípio da subsidiariedade - inexistência de outro meio eficaz de sanar a lesão - contido no art. $4^{\circ}, \S 1^{\circ}$, da Lei n. 9.882, de 1999, há de ser aquele apto a solver a controvérsia constitucional relevante de forma ampla, geral e imediata." 18

O requisito da subsidiariedade é, a nosso ver, outro elemento que contribui para a prática da autocontenção judicial e maior seletividade das questões políticas levadas ao STF, já que, mesmo presente o requisito da subsidiariedade nas arguições, os Ministros têm proferido decisões contrariamente à lei das ADPFs (Lei n $\left.{ }^{0} 9.882 / 99\right){ }^{19}$ : não são observados os requisitos estabelecidos na lei e decisões foram proferidas mesmo quando havia a possibilidade de utilização de outro meio apto a sanar a ameaça ou lesão. Com isso, há a desconsideração dos defeitos de forma nas ADPFs por parte do STF e do requisito da subsidiariedade, demonstrando que a instrumentalidade das formas seria um discurso utilizado pela nossa Suprema Corte para a prática da autocontenção judicial implícita e a seletividade dos casos que irão a julgamento.

Assim, conforme os interesses políticos envolvidos na causa, a subsidiariedade não é utilizada. Portanto, com essa prática, impede-se a ocorrência do julgamento, o que favorece a presença da autocontenção judicial implícita em sede de arguição de descumprimento de preceito fundamental.

Com a prática da autolimitação judicial, o processo decisório apresenta-se influenciado pelas ideologias do juiz, recebendo contornos políticos pela possibilidade de seus efeitos interferirem no resultado das políticas públicas. Dessa forma, existe interferência entre direito e política, uma vez que a norma representa a vontade da maioria legislativa e, ao decidir, o juiz adota posicionamento contra ou a favor dessa maioria ou das minorias. 


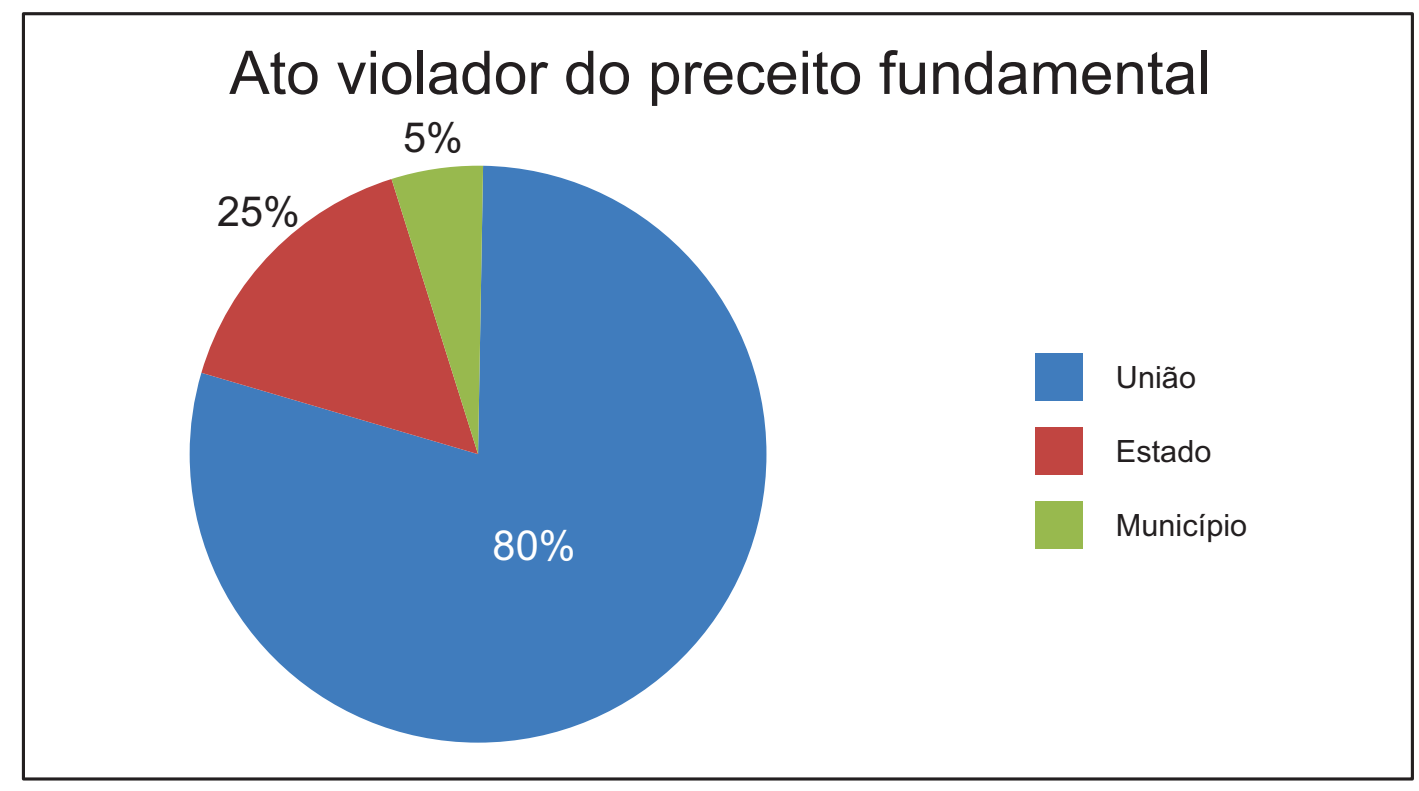

Gráfico 7 - Origem do ato violador do preceito fundamental

Fonte: elaboração própria, a partir de dados colhidos no sítio eletrônico do STF.

O Judiciário Federal foi o ente responsável pelo maior percentual de violações aos preceitos fundamentais ao aplicar e interpretar as normas editadas pela União, desse modo, foi o ente que mais sofreu controle concentrado de constitucionalidade nas ADPFs. Essas normas constituem, assim, os atos decorrentes dos poderes públicos objeto das arguições propostas pelos Governadores de Estado e confederações sindicais e entidades de classe de âmbito nacional.

O Poder Legislativo, ao contrário do que se poderia observar, é um dos poderes que menos ameaçou/violou os preceitos fundamentais - sua inércia na elaboração de normas e medidas em prol do Estado é um indicativo desse reduzido quantitativo de processos. Verifica-se que o Judiciário não decide as arguições nas quais ele próprio figurou como violador aos preceitos fundamentais, passando a analisar o mérito das ADPFs propostas contra o Poder Executivo.

Por fim, a comprovação das hipóteses apresentadas nessa pesquisa, referentes à investigação das causas de mudança no quadro de julgamento das arguições. Os assuntos objeto das arguições não são utilizados como mecanismo de restrição ao julgamento, no entanto, a partir da análise feita por ano de julgamento, verifica-se que eles contribuem para o aumento do número de processos decisórios efetivos.

Diferentemente dos assuntos, foi possível verificar que, em relação à admissibilidade das ADPFs, muitas não tiveram seguimento em decorrência de o ato questionado não ser considerado decorrente do poder público e, nesse caso, o tipo do ato praticado funcionou como elemento impeditivo de julgamentos. 
A partir dessas observações, foi verificado que os requerentes das ADPFs não constituem elemento responsável pela mudança no quadro de julgamento das arguições. A análise feita com relação aos legitimados ativos nas arguições revela que, no total de ações propostas e naquelas que sofreram julgamento, o maior beneficiado pelo processo decisório foi o Poder Executivo Estadual, o que reforça a hipótese de que os requerentes não constituem elemento responsável pela alteração na quantidade de julgamentos.

Foi possível também confirmar a hipótese de que, de acordo com a postura adotada pelos Relatores, haverá maior ou menor quantidade de ações julgadas. Quando analisada a amostra total das 275 ADPFs, lideraram o índice de não julgamento das arguições os Ministros Marco Aurélio, Ricardo Lewandowski e Joaquim Barbosa, situação em que é verificado o exercício da seletividade no julgamento das ADPFs pelo Supremo Tribunal Federal. No âmbito das arguições efetivamente julgadas, a seletividade foi característica fortemente presente, sendo verificada a manutenção de posicionamento mais seletivo pela maioria dos Relatores, com exceção do Ministro Luiz Fux, que decidiu o mérito de maior quantitativo de arguições.

Esses elementos demonstram a existência de intensa seletividade das questões pelo Supremo; as escolhas são possíveis em decorrência do aumento dos poderes de intervenção dos tribunais na arena política característica que, assim como na judicialização e ativismo, também está presente no âmbito da autocontenção judicial.

\section{CONCLUSÕES}

O Supremo Tribunal Federal tem adotado uma postura de abstenção voluntária em relação ao julgamento das $\mathrm{ADPF}$ devido a apresentarem como maior violador de preceitos fundamentais o próprio Poder Judiciário, que deveria zelar pelo respeito às garantias constitucionais e preceitos fundamentais previstos na Constituição da República Federativa do Brasil de 1988. Porém, em meio ao reduzido número de ADPFs julgadas, por meio dos Ministros Relatores, o Supremo seleciona algumas situações específicas suscitadas nessas arguições para serem julgadas em virtude de sua relevância, maior repercussão na sociedade e interesses políticos envolvidos.

Diante do contexto da judicialização das questões políticas e do ativismo judicial presente na jurisdição constitucional brasileira, verificou-se que as ADPFs têm sofrido limitações no que se refere ao processo decisório de suas ações, ocorridas principalmente em razão de grande parte das arguições de descumprimento apresentar como maior ente violador de preceitos fundamentais o Poder Judiciário. Desse modo, a restrição ocorre para que o Judiciário não perca seu poder de decisão e confiança nele depositada pela sociedade, considerado como único poder estatal capaz de solucionar os conflitos não finalizados pelos demais poderes. Esse é o principal elemento que fundamenta a ocorrência de autocontenção judicial nas ADPFs. 
Por meio das arguições julgadas e não julgadas, foi possível observar a ocorrência do conflito entre os Poderes Executivo e Judiciário nas questões levadas ao Supremo, uma vez que a maior parte das arguições propostas diz tanto respeito ao Poder Executivo, indicado como aplicador de normas inconstitucionais e violador dos preceitos fundamentais por intermédio de entes da administração pública, quanto às garantias e direitos fundamentais, sendo o mérito amparado pelo princípio da dignidade humana.

A afirmativa de que pouco é verificada a superposição entre os Poderes Executivo e Judiciário está equivocada: o Judiciário prioriza o julgamento das arguições oriundas de atos do poder público cuja origem é o Executivo e, com isso, beneficia-se, mantendo-se como poder que defende preceitos fundamentais constantemente violados pelo Executivo. $O$ não julgar, decorrente da seletividade, representa uma opção política, pois mantém os efeitos do ato impugnado, beneficiando o ente político que editou o ato. $\mathrm{O}$ mesmo efeito que ocorre quando do julgamento improcedente.

Inseridas no âmbito da autocontenção, as ADPFs constituem imprescindível meio de defesa dos preceitos fundamentais, admitido o acesso à revisão pelo Judiciário de forma concentrada e sendo capaz de proporcionar efeitos erga omnes - que atingem todas as demais situações em que o ato ou a norma objeto da impugnação transgrediu o direito fundamental previsto constitucionalmente. A partir desses resultados, espera-se contribuir para a compreensão das relações estratégicas entre os Poderes constituídos do Estado e ampliar os conhecimentos sobre os efeitos concretos do controle de constitucionalidade realizado mediante a utilização das arguições de descumprimento de preceito fundamental.

\section{REFERÊNCIAS}

BONAVIDES, Paulo. Jurisdição constitucional e legitimidade: algumas observações sobre o Brasil. Estudos Avançados, São Paulo, v. 18, n. 51, p. 127-150, 2004. Disponível em: $<$ http://www.scielo.br/scielo.php?script=sci_arttext\&pid $=$ S010340142004000200007\&ln $\mathrm{g}=\mathrm{en} \& \mathrm{nrm}=\mathrm{iso}>$. Acesso em: $10 \mathrm{jan} .2013$.

BRASIL. Constituição (1988). Constituição da República Federativa do Brasil. Brasília: Senado, 1988.

. Lei $\mathrm{n}^{0}$ 9.882, de 03 de dezembro de 1999. Dispõe sobre o processo e julgamento da arguição de descumprimento de preceito fundamental, nos termos do $\S 1^{\circ}$ do art. 102 da Constituição Federal. Diário Oficial [da] República Federativa do Brasil, Brasília, DF, 6 dez. 1999. Disponível em: < http://www.planalto.gov.br/ccivil_03/Leis/L9882.htm>. Acesso em: 7 out. 2012. 
. Supremo Tribunal Federal. ADPF n ${ }^{\circ}$ 3. Relator: Ministro Sidney Sanches. Diário de Justiça, Brasília, 27 nov. 2004. Disponível em: <http://www.stf.jus.br/portal/processo/ verProcessoAndamento.asp>. Acesso em: 21 jul. 2013.

CARVAlHO, Ernani Rodrigues de. Judicialização da Política no Brasil: controlo de constitucionalidade e racionalidade política. Análise Social, Lisboa, v. 44, n. 191, p. 315335, abr. 2009. Disponível em: <http://www.scielo.oces.mctes.pt/scielo.php?script $=$ sci arttext\&pid $=$ S0003-25732009000200004\&lng =pt\&nrm=iso $>$. Acesso em: 5 jun. 2013.

. Revisão judicial e judicialização da política no direito ocidental: aspectos relevantes de sua gênese e desenvolvimento. Revista de Sociologia e Política, Curitiba, n. 28, p. 161179, jun. 2007. Disponível em: <http://www.scielo.br/pdf/rsocp/n28/a11n28.pdf>. Acesso em: 5 jun. 2013.

DIMOULIS, Dimitri; LUNARDI, Soraya Gasparetto. Ativismo e autocontenção judicial no controle de constitucionalidade. In: FELLET, André Luiz Fernandes; PAULA, Daniel Giotti de; NOVELINO, Marcelo. As novas faces do ativismo judicial. Salvador: Juspodivm, 2011. p. 459-473.

MEDEIROS, Bernardo Abreu de. Ativismo, delegação ou estratégia? a relação inter poderes e a judicialização no Brasil. In: FELLET, André Luiz Fernandes; PAULA, Daniel Giotti de; NOVELINO, Marcelo. As novas faces do ativismo judicial. Salvador: Juspodivm, 2011. p. $529-540$.

MENDES, Gilmar Ferreira. Arguição de descumprimento de preceito fundamental: comentários à Lei no 9.882/99, de 3.12.1999. São Paulo: Saraiva, 2009.

. Jurisdição Constitucional no Brasil: o problema da omissão legislativa inconstitucional. In: CONGRESSO DA CONFERÊNCIA DE CORTES CONSTITUCIONAIS EUROPEIAS, 14., 2008, Vilnius. Anais eletrônicos... Vilnius: [s.n.], 2008. Disponível em: $<$ http://www.stf.jus.br/portal/cms/verNoticiaDetalhe.asp?idConteudo=90357\&sigServico $=$ noticiaArtigoDiscurso\&caixaBusca $=\mathrm{N}>$. Acesso em: 23 jan. 2013.

POSNER, Richard A. The Meaning of Judicial Self-Restraint. Indiana Law Journal, v. 59, n. 1, 1983. Disponível em: < http://www.repository.law.indiana.edu/ilj/vol59/iss1/1>. Acesso em: 24 maio 2013.

TAYLOR, Matthew M; ROS, Luciano da. Os partidos dentro e fora do poder: judicialização como resultado contingente da estratégia política. Revista Brasileira de Ciências Sociais, Rio de Janeiro, v. 51, n. 4, p. 825-864, 2008.

STRECK, Lenio Luiz. Jurisdição constitucional e hermenêutica: uma nova crítica do direito. 2. ed. Rio de Janeiro: Forense, 2004.

VAINER, Bruno Zilberman. A predominância do controle concentrado de constitucionalidade e as perspectivas de uma corte constitucional brasileira. Revista Brasileira de Direto 
Constitucional, n. 14, p. 197-271, jul./dez. 2009. Disponível em: <http://www.esdc.com. br/RBDC/RBDC-14/RBDC-14-197-Monografia_Bruno_Zilberman_Vainer_(Predominancia_do_Controle_Concentrado).pdf >. Acesso em: 11 jan. 2013.

WHITTINGTON, Keith E. Interpose your friendly hand: political supports for the exercise of judicial review by the United States Supreme Court. The American Political Science Review: American Political Science Association, v. 99, n. 4, nov. 2005. Disponível em: $<$ http://www.jstor.org/stable/30038966>. Acesso em: 9 jul. 2013.

1 BRASIL. Constituição (1988). Constituição da República Federativa do Brasil. Brasília: Senado, 1988.

2 BONAVIDES, Paulo. Jurisdição constitucional e legitimidade: algumas observações sobre o Brasil. Estudos Avançados, São Paulo, v. 18, n. 51, p. 127-150, 2004.p. 128. Disponível em: <http://www.scielo.br/scielo.php?script=sci_ar ttext\&pid=S010340142004000200007\&lng=en\&nrm=iso >. Acesso em: 10 jan. 2013.

3 TAYLOR, Matthew M; ROS, Luciano da. Os partidos dentro e fora do poder: judicialização como resultado contingente da estratégia política. Revista Brasileira de Ciências Sociais, Rio de Janeiro, v. 51, n. 4, p. 825-864, 2008. p. 826.

4 TAYLOR, Matthew M; ROS, Luciano da. Os partidos dentro e fora do poder: judicialização como resultado contingente da estratégia política. Revista Brasileira de Ciências Sociais, Rio de Janeiro, v. 51, n. 4, p. 825-864, 2008. p. 826.

5 MEDEIROS, Bernardo Abreu de. Ativismo, delegação ou estratégia? a relação inter poderes e a judicialização no Brasil. In: FELLET, André Luiz Fernandes; PAULA, Daniel Giotti de; NOVELINO, Marcelo. As novas faces do ativismo judicial. Salvador: Juspodivm, 2011. p. 529-540. p. 530.

6 STRECK, Lenio Luiz. Jurisdição constitucional e hermenêutica: uma nova crítica do direito. 2. ed. Rio de Janeiro: Forense, 2004. p. 456.

7 VAINER, Bruno Zilberman. A predominância do controle concentrado de constitucionalidade e as perspectivas de uma corte constitucional brasileira. Revista Brasileira de Direto Constitucional, n. 14, p. 197-271, jul./dez. 2009. p. 224. Disponível em: < http://www.esdc.com.br/RBDC/RBDC-14/RBDC-14-197-Monografia_Bruno_Zilberman_Vainer_(Predominancia_do_Controle_Concentrado).pdf >. Acesso em: 11 jan. 2013.

8 MENDES, Gilmar Ferreira. Jurisdiç̧ão Constitucional no Brasil: o problema da omissão legislativa inconstitucional. In: CONGRESSO DA CONFERÊNCIA DE CORTES CONSTITUCIONAIS EUROPEIAS, 14., 2008, Vilnius. Anais eletrônicos... Vilnius: [s.n.], 2008. p. 6. Disponível em: <http://www.stf.jus.br/portal/cms/verNoticiaDetalhe. asp?idConteudo $=90357 \&$ sigServico $=$ noticiaArtigoDiscurso\&caixaBusca $=\mathrm{N}>$. Acesso em: 23 jan. 2013.

9 CARVALHO, Ernani Rodrigues de. Revisão judicial e judicialização da política no direito ocidental: aspectos relevantes de sua gênese e desenvolvimento. Revista de Sociologia e Política, Curitiba, n. 28, p. 161-179, jun. 2007. p. 162. Disponível em: <http://www.scielo.br/pdf/rsocp/n28/a11n28.pdf>. Acesso em: 5 jun. 2013.

10 CARVALHO, Ernani Rodrigues de. Judicialização da Política no Brasil: controlo de constitucionalidade e racionalidade política. Análise Social, Lisboa, v. 44, n. 191, p. 315-335, abr. 2009. Disponível em: <http://www.scielo. oces.mctes.pt/scielo.php?script $=$ sci_arttext\&pid $=$ S0003-25732009000200004\&lng $=$ pt\&nrm $=$ iso $>$. Acesso em: 5 jun. 2013.

11 CARVALHO, Ernani Rodrigues de. Judicialização da Política no Brasil: controlo de constitucionalidade e racionalidade política. Análise Social, Lisboa, v. 44, n. 191, p. 315-335, abr. 2009. Disponível em: <http://www.scielo. oces.mctes.pt/scielo.php?script $=$ sci_arttext\&pid $=$ S0003-25732009000200004\&lng $=$ pt\&nrm $=$ iso $>$. Acesso em: 5 jun. 2013.

12 POSNER, Richard A. The Meaning of Judicial Self-Restraint. Indiana Law Journal, v. 59, n. 1, 1983. p. 1. Disponível em: <http://www.repository.law.indiana.edu/ilj/vol59/iss1/1>. Acesso em: 24 maio 2013.

13 DIMOULIS, Dimitri; LUNARDI, Soraya Gasparetto. Ativismo e autocontenção judicial no controle de constitucionalidade. In: FELLET, André Luiz Fernandes; PAULA, Daniel Giotti de; NOVELINO, Marcelo. As novas faces do ativismo judicial. Salvador: Juspodivm, 2011. p. 459-473. p. 468. 
14 WHITTINGTON, Keith E. Interpose your friendly hand: political supports for the exercise of judicial review by the United States Supreme Court. The American Political Science Review: American Political Science Association, v. 99, n. 4, nov. 2005. Disponível em: < http://www.jstor.org/stable/30038966>. Acesso em: 9 jul. 2013. p. 584.

15 BRASIL. Lei no 9.882, de 03 de dezembro de 1999. Dispõe sobre o processo e julgamento da arguição de descumprimento de preceito fundamental, nos termos do $\S 1^{\circ}$ do art. 102 da Constituição Federal. Diário Oficial [da] República Federativa do Brasil, Brasília, DF, 6 dez. 1999. Disponível em: <http://www.planalto.gov.br/ccivil_03/ Leis/L9882.htm >. Acesso em: 7 out. 2012.

16 BRASIL. Lei no 9.882, de 03 de dezembro de 1999. Dispõe sobre o processo e julgamento da arguição de descumprimento de preceito fundamental, nos termos do $\S 1^{\circ}$ do art. 102 da Constituição Federal. Diário Oficial [da] República Federativa do Brasil, Brasília, DF, 6 dez. 1999. Disponível em: <http://www.planalto.gov.br/ccivil_03/ Leis/L9882.htm >. Acesso em: 7 out. 2012.

17 BRASIL. Supremo Tribunal Federal. ADPF n 3. Relator: Ministro Sidney Sanches. Diário de Justiça, Brasília, 27 nov. 2004. Disponível em: <http://www.stf.jus.br/portal/processo/verProcessoAndamento.asp >. Acesso em: 21 jul. 2013.

18 MENDES, Gilmar Ferreira. Arguição de descumprimento de preceito fundamental: comentários à Lei n⿳ 9.882/99, de 3.12.1999. São Paulo: Saraiva, 2009. p. 180.

19 BRASOL. Lei n ${ }^{\circ}$ 9.882, de 03 de dezembro de 1999. Dispõe sobre o processo e julgamento da arguição de descumprimento de preceito fundamental, nos termos do $\S 1^{\circ}$ do art. 102 da Constituição Federal. Diário Oficial [da] República Federativa do Brasil, Brasília, DF, 6 dez. 1999. Disponível em: <http://www.planalto.gov.br/ccivil_03/ Leis/L9882.htm >. Acesso em: 7 out. 2012.

SELF-RESTRAINT IN THE BRAZILIAN JUDICIARY: AN ANALYSIS OF STRATEGIC RELATIONS AMONG THE BRANCHES OF THE STATE

The claim of breach of fundamental precept (arguição de descumprimento de preceito fundamental - ADPF) is a typically Brazilian procedural constitutional instrument, aimed at preventing threats or violations of fundamental precept by the government. The excessive recourse to the Judiciary and judicial activism in the Brazilian Supreme Court (STF) highlights the small number of ADPF that have been judged by the Court. We intend to draw the empirical profile of the functioning of judicial review through the judgement of ADPFs and to analyze the occurrence of judicial self-restraint and the behavior of judges when rendering decisions relating to ADPFs. We attempted to understand the selectivity in the judgements of ADPFs by the STF, specifying the elements that motivated the effective decision-making and the factors that allow the practice of self-restraint by the Brazilian Supreme Court. We concluded there is a conflict between the Executive and the Judiciary: many of the ADPFs that were filed indicate the Judiciary itself as perpetrator of the alleged breach. However, when selecting which ADPFs to judge, this branch will usually prefer to decide those in which the Executive branch is the 
respondent, thus impeding the conclusion of cases questioning acts by the Judiciary and the recognition of said branch as the most frequent offender of fundamental rights and guarantees. Through quantitative and qualitative analysis, we sought to understand the positive and negative selectivity in the judgment of ADPFs carried out by the Supreme Court. We analyzed the cases that have not been judged on the merits and those that have, in the period between 1993 and 2013. We also analyzed the behavior of Judges of the Supreme Court regarding the subsidiarity requirement and the observance of the Law 9.882/99, which regulates ADPFs. The procedural monitoring of all ADPFs was accomplished via the Brazilian Supreme Court website (www.stf.jus.br). We expect that this research will contribute to the understanding of the strategic relations between the branches of the State.

Keywords: Judicial self-restraint. State branches. Claim of breach of fundamental precept. Selectivity.

Submetido: 14 mar. 2017

Aprovado: 6 jun. 2017 